\title{
CONSTITUTIONAL LAW: SUPREME COURT AVOIDS CONSTITUTIONAL QUESTION OF STATE ACTION IN SIT-IN CASES BY EXTENDING THE DOCTRINE OF ABATEMENT
}

$\mathrm{I}_{\mathrm{N}}$ N THE WAKE of the Civil Rights Act of $1964,{ }^{1}$ courts have been left with the disposition of convictions arising from the civil disobedience which served as a prime mover of legislative action. The dilemma these convictions posed involved two conflicting values: the aged tenet that social order requires adherence to all laws, no matter how arbitrary, and a genuine sympathy with the rights asserted by the demonstrators. The added sanction given these claims by the Civil Rights Act provided the Supreme Court with a vehicle to reverse many of the convictions in Hamm v. City of Rock Hill, while avoiding a constitutional decision on the "right" to service at places of public accommodation.

The Hamm decision embodied two consolidated cases $^{3}$ with essentially identical facts. The defendants had participated in sit-in demonstrations at luncheon facilities of retail stores, and were convicted under state trespass statutes when they ignored requests to leave. 4 The appeals from these convictions were pending in the Supreme Court when the Civil Rights Act became effective. ${ }^{5}$ Justice Clark, writing for the majority of the Court, vacated the convictions on the ground that the pending convictions should be abated because the Civil Rights Act "removes peaceful attempts to be served

\footnotetext{
178 Stat. 241 (1964).

2379 U.S. 306 (1964).

${ }^{3}$ Lupper v. State, 236 Ark. 596, 367 S.W.2d 750 (1963); City of Rock Hill v. Hamm, 241 S.C. 420 , 128 S.E.2d 907 (1962).

-The Arkansas statute provides that persons "who after having entered the business premises of any other person, firm, or corporation, other than a common carrier, and who shall refuse to depart therefrom upon request of the owner or manager . . . shall be deemed guilty of a misdemeanor ... ." ARk. Stat. ANN. § 41-1433 (1964). The corresponding South Carolina provision is quite similar: "Any person . . . who, having entered into the ... place of business ... of another person without having been warned within six months not to do so, and fails and refuses, without good cause or good excuse, to leave immediately upon being ordered or requested to do so by the person in possession or his agent or representative shall, on conviction, be fined ... or be imprisoned ...." S.C. CoDE ANN. \$ 16-388 (1962).

${ }^{5}$ The act became law on July 2, 1964. 78 Stat. 241 (1964). Certiorari was granted in Lupper and Hamm on June 22, 1964. Lupper v. Arkansas, 377 U.S. 989 (1964); Hamm v. City of Rock Hill, 377 U.S. 988 (1964).
} 
on an equal basis from the category of punishable activities." ${ }^{\circ}$ The decision drew pointed dissents from Justices Black, Harlan, Stewart and White. ${ }^{7}$

The doctrine of abatement utilized by the Court is of common law origin, ${ }^{8}$ and generally requires setting aside pending judgments rendered under the ambit of a law since changed or repealed by a supervening statute. ${ }^{9}$ It is a judicially-evolved rule of construction which, absent a contrary manifestation, imputes to the legislature an intention to avoid punishment "when it can no longer further any legislative purpose."10 Before Hamm, the doctrine had ordinarily been invoked only in cases where a criminal statute was expressly repealed.11 In one instance, however, pending prosecutions under the National Prohibition Act were vacated although the act had not been expressly repealed. That decision was predicated on the ground that adoption of the twenty-first amendment removed the act's constitutional foundation..$^{12}$

In applying the doctrine to the convictions in Hamm, the Court first noted that both establishments involved were clearly encompassed within the purview of the public accommodations section of the Civil Rights Act. ${ }^{13}$ Since that provision made "nonforcible at-

- 379 U.S. at 308.

IId. at 318 (Black, J.), 322 (Harlan, J.), 326 (Stewart, J.), 327 (White, J.).

${ }^{8}$ The earliest recognition of abatement is found in 1 HALE, PLEAS OF THE Crown 291 (1680). The doctrine was first introduced in the United States in 1801, United States v. Schooner Peggy, 5 U.S. (1 Cranch) 103, 110 (1801), and has been adopted by state as well as federal courts. See Hamm v. City of Rock Hill, 379 U.S. 306, 323 (Harlan, J., dissenting). A cogent statement of the rule as fully formulated by the common law is found in State $v$. Allen: "[T] tion, thereunder, without any saving clause as to such prosecution, will prevent its being further prosecuted; and this rule applies as well after judgment and sentence pending an appeal duly taken therefrom as before the final determination in the trial court." 14 Wash. 103, 105, 44 Pac. 121, 122 (1896). See generally Levitt, Repeal of Penal Statutes and Effect on Pending Prosecutions, 9 A.B.A.J. 715 (1923).

- 379 U.S. at $312-13$.

10 Id. at 313 .

11 The Civil Rights Act does not "repeal" state trespass statutes, but merely prevents them from being invoked to prosecute adamant Negroes who remain on business premises when refuscd public accommodation. Id. at 310-11. The length of time demonstrators may remain in a store demanding service remains an open question. See id. at 318 (Black, J., dissenting).

12 United States v. Chambers, 291 U.S. 217, 222-23 (1934).

${ }^{18} 379$ U.S. at $309-10$. The statute forbids racial discrimination in places of public accommodation whose operations affect commerce, including lunch counters and similar facilities "located on the premises of any retail establishment." Civil Rights Act of 1964, tit. Il, $\S 201$ (b) (2), 78 Stat. 243 (1964). An establishment which serves or offers to serve interstate travelers, or which serves a substantial portion of food which has moved in interstate commerce is subject to the Civil Rights Act of 1964, tit. II, $\S 201$ (c) (2), 78 Stat. 243 (1964). The consolidated cases in Hamm involved the tearoom 
tempts to ... remain in establishments covered by the Act" immune from prosecution under state trespass statutes, ${ }^{14}$ the conduct of the defendants would not have been punishable had it occurred after passage of the act. Although no previous case had applied the doctrine of abatement interjurisdictionally to give a federal statute the effect of retroactively exculpating convictions under state criminal statutes, ${ }^{16}$ the majority deemed the distinction specious. ${ }^{16}$ Interjurisdictional abatement was accomplished through the conduit of the supremacy clause, ${ }^{17}$ over the dissenters' strenuous objection that this unprecedented incursion into the states' criminal law prerogatives could not be so cavalierly assumed without a clear expression by Congress that the statute was to have that effect. ${ }^{18}$ To the majority, however, the dearth of discussion of retroactive clemency in the act's legislative history did not preclude imputing the requisite intent to Congress. ${ }^{19}$

Imputing the intent to abate pending convictions posed an additional obstacle for the majority. The federal Savings Statute provides that the repeal of a statute shall not release any penalty or prosecution incurred thereunder "unless the repealing Act shall so expressly

and lunch counter of a large department store and a sizeable variety store. The application of the provisions to these stores was not seriously contested. 379 U.S. at 309-10. Cf. Katzenbach v. McClung, 379 U.S. 294 (1964) (Congress has the power to extend Title II to a small restaurant which serves a substantial amount of food having moved in interstate commerce).

Justice Harlan, dissenting in Hamm, argued that it would be difficult to show that past trespass convictions placed a burden on present interstate commerce. Thus, an extension of the act to these convictions, he argued, had a tenuous constitutional foundation. 379 U.S. at 325 . This posed no constitutional difficulty to Justices Douglas and Goldberg, however, as they predicated their sanction of the Civil Rights Act on Congressional power to enforce the equal protection clause of the fourtcenth amendment as well as its legislative power under the commerce clause. Id. at 317 (concurring opinion). See Heart of Atlanta Motel, Inc. v. United States, 379 U.S. 241, 279-86 (1964) (Douglas, J., concurring).

14379 U.S. at 311 .

IV Id. at 323-24. (Harlan, J., dissenting).

${ }^{16} \mathrm{Id}$. at 314 . The majority termed the interjurisdictional problem a "distinction without a difference." Ibid.

${ }^{17}$ Id. at 315. The majority opinion reasoned that the Civil Rights Act was intended to be a defense against criminal trespass prosecutions. State statutory trespass convic. tions at variance with this federal purpose were void under the supremacy clause of the Constitution. U.S. CoNsT. art. VI, § 2. Compare Fill v. Florida, 325 U.S. 538 (1945), holding that to the extent a state labor statute is in a given situation repugnant to the National Labor Relations Act, the former is of no effect.

18379 U.S. 319 (Black, J., dissenting); id. at 324 (Harlan, J., dissenting); id. at 32728 (White, J., dissenting). "Our federal system tolerates wide differences between state and federal legislative policies." Id. at 323 (Harlan, J., dissenting).

${ }^{20}$ " $[W]$ e deem it irrelevant that Congress made no allusion to the problem in enacting the Civil Rights Act." Id. at 314. 
provide." ${ }^{20}$ Although Justice Black argued that this statute required a clear manifestation of congressional intent to abate, ${ }^{21}$ the majority construed the Savings Statute to avert only a "technical" abatement resulting from a "repeal" which altered some minor element or penalty of the offense but substantially reenacted the old crime..$^{22}$ The Civil Rights Act was no such technical repealer or amendment-it substituted a right to be free from punishment for seeking service for the former crime proscribed by state trespass laws. ${ }^{23}$ To the majority, this sweeping vindication of the rights asserted by the sit-in transcended the narrow purpose of the Savings Statute and gave the assertion of those rights a sanction which is implemented by the doctrine of abatement.

The construction given to the Savings Statute by the majority ignored persuasive precedent in which the Supreme Court had ruled that the repeal of a substantive federal crime did not exonerate a defendant who violated the law while still in effect. The Savings Statute was deemed to have kept the repealed law in force for purposes of pending prosecutions. ${ }^{24}$ Justice Black excoriated the Court's "technical repealer" rule and asserted that it had no support "in the language of the statute, in its legislative history, or in subsequent decisions under it."25

In dealing with the issue of civil disobedience against laws with

${ }^{20} 1$ U.S.C. $\$ 109$ (1958).

21379 U.S. at $319-20$.

${ }^{22}$ Id. at 314 . The majority argued that the Savings Statute was designed to avoid the results obtained in United States v. Tynen, 78 U.S. (11 Wall.) 88 (1870) and Norris v. Crocker, 54 U.S. (13 How.) 429 (1851), where abatement was predicated on a technical repealer. See also Levitt, supra note 8 , at 717 . Mr. Justice Harlan accepted the majority's conclusion that the statute was inapplicable on the ground that it dealt only with repeal or amendment of federal, not state statutes. 379 U.S. at 322-23 n.l (dissenting opinion).

${ }^{23}$ Sections 201 and 202 define the right to full enjoyment of all public accommodations coming within the act, and 203 (c) provides that no authority shall "punish or attempt to punish any person for exercising or attempting to exercise any right or privilege secured by section 201 or 202." 379 U.S. at 311. Civil Rights Act of 1964, tit. II, $\$ \S 201-03,78$ Stat. $243-44$ (1964).

${ }^{24}$ In United States v. Reisinger, 128 U.S. 398 (1888), the defendant was convicted for a crime occurring in 1883 which was totally repealed in 1884 . The Court recognized that although common law abatement would have been sufficient to reverse his conviction, the absence of a clause giving retroactive effect to repeal precluded abatement under the Savings Statute. See Great Northern Ry. v. United States, 208 U.S. 452 (1908), where the Court noted that the Savings Statute was to be "treated as if incorporated in and as a part of subsequent enactments . . . unless either by express declaration or necessary implication, arising from the terms of the law, as a whole, it results that the legislative mind will be set at naught by giving effect to the provisions of $\S 13$." Id. at 465 .

${ }_{25} 379$ U.S. at 320 n.3. 
which the demonstrators disagree, abatement, when viewed in policy terms, is perhaps an appropriate mantle under which the result in Hamm can be rationalized. Traditionally, courts have justified the release of pending convictions under a since-repealed law by reference to general notions of justice. The underlying rationale is that any guilt attached to the act is expurgated by the repealer, since punishment of an act no longer unlawful would be unconscionable. ${ }^{2 B}$ Similarly, the rights non-violently demonstrated for in Hamm were vindicated by the Civil Rights Act, whose "great purpose ... was to obliterate the effect of a distressing chapter of our history." 27 It was in the spirit of this "great purpose" that the majority absolved the demonstrators. ${ }^{28}$ To at least three of the dissenters, however, judicial sympathy for the rights asserted afforded no pretext for condoning self-help. ${ }^{20}$ They voiced the counterbalancing policy argument that the criminal law purports to make acts unlawful at the time when perpetrated. This view of criminal philosophy posits the proposition that deliberate transgressions of existing law endanger the fabric of social order and should be punished unless the legislature explicitly provides to the contrary. In Justice Black's view, the Civil Rights Act provides only a civil remedy, and by no construction does it authorize "persons who are unlawfully refused service a 'right' to take the law into their own

${ }^{20}$ See Levitt, supra note 8 , at 716 . Other, more artificial reasons given to justify the use of abatement are listed by Levitt as "the absence of a law to be enforced by the courts; ... the absence of an offense to be punished; ... the absence of power in the court to proceed with the prosecution." Ibid. Such formulations state the legal result rather than provide penetrating policy foundations for utilization of the doc. trine.

${ }^{27} 379$ U.S. at 315 . Justice Clark paraphrased this statement later in his opinion to emphasize the broad scope of the Civil Rights Act: "As we have said, Congress as well as the two Presidents who recommended the legislation, clearly intended to eradicate an unhappy chapter in our history." Ibid. (Emphasis added.)

28 "The peaceful conduct for which petitioners were prosecuted was on behalf of a principle since embodied in the law of the land. The convictions were based on the theory that the rights of a property owner had been violated. However, the supposed right to discriminate on the basis of race . . . was nullified by the statute. Under such circumstances the actionable nature of the acts in question must be viewed in the light of the statute and its legislative purpose." Id. at 315-16.

${ }^{20}$ Justices Black, Harlan and White denounced the majority's sanction of civil disobedience. Id. at 318-19 (Black, J., dissenting); id. at 322 (Harlan, J., dissenting); id. at 328 (White, J., dissenting). Justice Stewart, however, reasoned that in the absence of an explicit expression of Congressional intent, any abatement should be discretionary with the states where the convictions arose. Thus, the convictions should be remanded to the states for their consideration in the same manner tliat trespass convictions were disposed of in Bell v. Maryland, 378 U.S. 226 (1964). 379 U.S. at $326-27$; see note 15 supra. 
hands by sitting down and occupying the premises for as long as they choose to stay." 30

The effect of applying abatement was also to enable the Court to avoid the constitutional issue, and it is perhaps for this reason that the artifice of abatement was invoked. The substantive question most extensively argued in the parties' briefs was whether the prosecution and conviction of sit-in demonstrators in places of public accommodation constituted state action of a judicial nature prohibited by the fourteenth amendment. ${ }^{31}$ The Court had previously reversed similar sit-in convictions pursuant to a variety of rationales artfully designed to avoid a constitutional decision. ${ }^{32}$ These decisions reflected a court divided both on the merits of the equal protection claim and on the propriety of a bold judicial intrusion into spheres of private discrimination at a time when it was a volatile political issue. The 1964 Bell $v$. Maryland case, ${ }^{33}$ a harbinger of the Hamm decision, presented the conflicting forces within the Court in their clearest focus. The context was similar to Hamm: sit-in demonstrators in a Baltimore restaurant were convicted under state trespass statutes. Subsequently, while their appeal was pending in the Supreme Court, both the city of Baltimore and the state

\footnotetext{
${ }^{30} 379$ U.S. at 318 (dissenting opinion).

32 The defendants in Hamm placed major reliance on an extension of the doctrine of Shelley v. Kraemer, 334 U.S. 1 (1948), which extended state action to enforcement by the state judiciary of private housing discrimination through the use of restrictive covenants. To the demonstrators, enforcement of private discrimination in accom. modations through the application of state trespass laws was likewise a form of state action which should invoke the substantive guarantees of the fourteenth amendment. Brief for Petitioners, pp. 51-57. For discussions of the constitutional question involved, see Abernathy, Expansion of the State Action Concept Under the Fourteenth Amendment, 43 CoRnelr L.Q. 375 (1958); Gilbert, Theories of State Action as Applied to the "Sit-In" Cases, 17 ARK. L. REv. 147 (1963); Henkin, Shelley v. Kraemer: Notes for a Revised Opinion, 110 U. PA. L. REv. 473 (1962); Karst \& Van Alstyne, Comment: Sit-Ins and State Action-Mr. Justice Douglas, Concurring, 14 STAN. L. REv. 762 (1962); Lewis, The Meaning of State Action, 60 CoLum. L. REv. 1083 (1960); Van Alstyne, Mr. Justice Black, Constitutional Review, and the Talisman of State Action, 1965 Dure L.J. 219; Williams, The Twilight of State Action, 4 I TeXAs L. REv. 347 (1963).

${ }^{32}$ E.g., Bell v. Maryland, 378 U.S. 226 (1964) (trespass convictions remanded to state court for consideration of the abating effect of a subsequent state accommodations statute); Robinson v. Florida, 378 U.S. 153 (1964) (convictions reversed because a state health regulation requiring separate rest rooms in restaurants amounted to state discouragement of integrated eating facilities in denial of equal protection); Bouie v. City of Columbia, 378 U.S. 347 (1964) (convictions reversed on the ground that state statutes did not give "fair warning" that conduct was criminal); Barr v. City of Columbia, 378 U.S. 146 (1964) (evidence insufficient to support convictions); Griffin v. Maryland, 378 U.S. 130 (1964) (convictions reversed because amusement park officer who requested defendants to leave was also a deputy sheriff and was thus enforcing private segregation by state action).

${ }^{33} 378$ U.S. 226 (1964). See notes 29 and 32 supra.
} 
of Maryland passed public accommodation laws. ${ }^{34}$ The Court remanded the convictions to the state court for a reconsideration of the cases in light of the new statutes. In doing so, the Court referred the state tribunal to the doctrine of abatement and advanced a number of reasons why its application would be efficacious in reviewing the convictions. ${ }^{35}$

The Bell decision was issued during the final days of the debate on the Civil Rights Act, and the opinion of the Court studiously avoided the constitutional question with this in mind. ${ }^{36}$ Six Justices were willing to decide the merits of the state action claim: Justices Douglas, Goldberg and Warren concluded, in concurring opinions, that the fourteenth amendment protected the right to public accommodation in these cases, ${ }^{37}$ and Justices Harlan and White joined Justice Black's dissenting argument that such discrimination was beyond the pale of state action. ${ }^{38}$ It is reasonable to assume that the remaining three Justices were reluctant to let the convictions stand, but were equally unwilling to consider the constitutional question when legislative action seemed imminent. Thus they settled on the abatement theory, thereby avoiding adding fuel to the heated public controversy then taking place. ${ }^{30}$

\footnotetext{
36 MD. ANN. CoDE art. 49B, § 11 (Supp. 1964); Baltimore, Md., Ordinance 1249, June 8, 1962, amending BALTmore, MD., CITY CODE art. 14A (1950).

${ }^{3 s}$ The Court noted that the Maryland savings statute could be disregarded because of the unique nature of the state public accommodations statute. The Supreme Court viewed the new legislation as beyond the scope of an ordinary repeal; rather, it sub. stituted a right for a crime. In view of these considerations, the majority concluded that there were cogent reasons for the state courts to abate the convictions. 378 U.S. at 233-37. An almost identical approach was utilized in Hamm when the Court was faced with a federal public accommodations law. See text accompanying note 23 supra.

${ }^{30}$ The dissenters in Bell were careful to intimate that none of the contentions advanced should be read as casting doubt on the power of Congress to compel private businesses to end racial discrimination. Id. at 349 .

${ }^{37}$ Justice Douglas found state action in the judicial enforcement of trespass laws having the effect of denying Negroes access to public accommodations. Id. at 255.59. He also suggested that the right to travel was an incident of national citizenship which was substantially impaired by a lack of public accommodation. Id. at 250.52. Justices Goldberg and Warren argued that the fourteenth amendment was intentionally designed to embody the common law innkeeper's duty to provide facilities for all, regardless of race. Id. at 296-97.

${ }_{38}$ The dissenters argued that property owners have, in the absence of statute, the right to choose business visitors or social gnests as they please, free from fourteenth amendment restrictions. Id. at 328-32.

${ }^{30}$ This approach was criticized by Mr. Justice Douglas as "frivolous" and an "ob. vious pretense." "The clash between Negro customers and white restaurant owners is clear.... Yet we leave resolution of the conflict to others, when, if our voice were heard, the issues for the Congress and for the public would become clear and prccise.
} 
The Court's direction was again dictated by these "swing" Justices in Hamm, for closely analogous reasons. Not only were they still averse to facing the substantive issue squarely, ${ }^{40}$ but now the pressing need for such a sweeping decision was nonexistent. The Civil Rights Act had recognized the right and provided efficient methods for implementing it. In this relatively sterile context, they were willing to express symbolic empathy, but not a controversial extension of state action to an area where they themselves were still in a state of decisional flux.

The enactment of a broadly remedial public accommodations law and the subsequent decision in Hamm makes it unlikely that the Court will face the constitutional issue in the near future. Remedies under the statute make such a claim unnecessary, except in cases where the establishment involved is not covered by the act. ${ }^{41}$ Hamm's immediate significance is in its application to pending convictions in analogous disobedience cases. The decision is clearly binding on other sit-in cases, but to abate similar convictions arising from assertions of different rights, sanction for those rights must be found in some provision of the Civil Rights Act. Sit-ins at theaters and stadiums are clearly exculpated, ${ }^{42}$ but activities such as mass voter registration demonstrations pose thornier problems..$^{43}$ Any act must be "non-violent" to invoke the abatement

The Court was created to sit in troubled times as well as in peaceful days." Id. at 243 (concurring opinion).

10 The Court chose not to determine whether the Civil Rights Act of 1964 was an exercise of Congressional power under $\S 5$ of the fourteenth amendment. 379 U.S. at 316. Judicial sanction of the act in this manner might have implied recognition of a fourteenth amendment right to public accommodation, and to avoid any division on this question the Court chose the more expedient justification provided by the commerce clause. See Heart of Atlanta Motel, Inc. v. United States, 379 U.S. 241, 250 (1964). Compare the concurring opinions of Justices Douglas and Goldberg, who wished to rest the decision on the fourteenth amendment ground as well. Id. at 279, 292.

"Situations falling outside the scope of the Civil Rights Act are rare. Justice Black, in a related context, may have adverted to such a possibility: "[S]ome isolated and remote lunch room which sells only to local people and buys almost all its supplies in the locality may possibly be beyond the reach of the power of Congress to reguate commerce ...."Id. at 275 (Black, J., concurring).

"2 Section 201 (a) (3) of title II designates "any motion picture house, theater, concert hall, sports arena, stadium or other place of exhibition or entertainment" as a place of public accommodation within the provisions of the act. Civil Rights Act of 1964, § 201 (a) (3), 78 Stat. 243 (1964).

10 Whereas the right to service at places of public accommodation conferred by the act necessarily includes a right to sit at the counter long enough to request service, sit-ins protesting voter registration procedures do not lend themselves as readily to characterization as a direct assertion of a "right." Although the right to vote is clear, and title I of the act restricts the use of literacy tests, nothing in the Civil Rights Act 
prescribed by Hamm, a proviso which admits of several possible interpretations. ${ }^{44}$

On the whole, however, the abatement doctrine as an organic branch of law would appear to have been given no great genetic impetus by the Court in Hamm. Its great utility was pretextual rather than conceptual, 45 and the Supreme Court's tortuous application of the doctrine affords a rare inner view not only of the Court's divisions but also of its sense of timing and its decisionmaking processes.

establishes a right to protest a deprivation thereof by means of a sit-in. It is arguable, however, that the distinction between this and lunchroom sit-ins is merely a matter of degree.

"The majority emphasized that "peaceful" and "non-forcible" attempts to gain admittance to or service in places of public accommodation were "immunized from prosecution" by the Civil Rights Act. 379 U.S. at 308, 311, 315. This requirement of "non-violence" might be taken by state courts as a rationale for affirming convictions which on their facts involved some degree of force or resistance to arrest.

${ }^{45}$ Justice Clark conceded that the abatement device conveniently enabled the Court to avoid the fourteenth amendment question. "Since this point is not free from doubt ... we avoid that [constitutional] question by favoring an interpretation of the statute which renders a constitutional decision unnecessary." Id. at 316. 